\title{
EFFECTS OF INCREASED EXPIRATORY PRESSURE ON BLOOD GAS TENSIONS AND PULMONARY SHUNTING DURING THORACOTOMY WITH USE OF THE CARLENS CATHETER
}

\author{
Sait Tarhan, M.D., and Richard O. Lundborg, M.D.*
}

THE ORIGINAL USE of the Carlens catheter in thoracic surgery was to prevent contamination of healthy lungs with secretions. Today it is widely used also to obtain an optimal operating exposure by excluding the lung in the opened hemithorax from the anaesthetic system. ${ }^{1}$

Extremely low arterial oxygen tensions may occur with this technique because of intentional collapse of the non-dependent lung and atelectasis in the dependent lung, resulting in excessive pulmonary shunting. ${ }^{2}$ It is known that during thoracic surgery, with the patient in the lateral decubitis position and the nondependent pleural space open, the mediastinum tends to shift towards the dependent lung by gravity and further increases the possibility of atelectasis on that side. To overcome this shifting, some positive airway pressure in the dependent lung throughout the expiratory phase is often required. ${ }^{3}$ It has been reported that higher arterial oxygen tensions can be obtained with increased expiratory pressures during non-thoracic surgery. ${ }^{4}$ Theoretically, controlled ventilation during thoracic surgery with increased expiratory pressures could prevent both mediastinal shifting and atelectasis, expand collapsed alveoli, and decrease pulmonary shunting in the dependent lung. This, in turn, would incrcase arterial oxygen tensions. This study was an effort to evaluate this concept.

\section{Material and Procedure}

Fourteen patients were studied; seven had lobectomy, three had pneumonectomy, one had wedge resection, two had exploratory thoracotomy, and one had division of a patent ductus arteriosus. Their ages ranged from 36 to 76 years (average 60). Total anaesthesia time ranged from 140 to 220 minutes. All patients were premedicated with $6-8 \mathrm{mg}$ of morphine sulphate, $0.4 \mathrm{mg}$ of atropine, and $100 \mathrm{mg}$ of sodium pentobarbital. Sodium thiopental (Pentothal Sodium), 200-500 mg, was administered for induction, after which 60-80 $\mathrm{mg}$ of succinylcholine were given for intubation with the Carlens catheter. Anaesthesia was maintained with 100 per cent oxygen and 1 per cent halothane (Fluothane).

All patients had manually controlled ventilation with a gas flow of 5 litres through a semiclosed circle system with carbon dioxide absorption. Minute ventilation was adjusted as necessary to prevent retention of carbon dioxide. All patients were in the lateral decubitus position during anaesthesia. A drip of 0.2 per cent succinylcholine was used intermittently as needed for relaxation. The

- Mayo Clinic and Mayo Foundation, Section of Anesthesiology, Rochester, Minnesota. 
total dose of succinylcholine, including the amount given for intubation, ranged from 200 to $600 \mathrm{mg}$.

Shortly before induction of anaesthesia a blood sample was drawn from the femoral artery, with the patient breathing air. Subsequent samples were obtained through a \#16 plastic needle from the radial artery in the following order: shortly after the pleural cavity was opened with both lungs ventilated; ten minutes after collapse of the non-dependant lung, using expiratory and inspiratory pressures of 0 and $30 \mathrm{~cm} \mathrm{H}_{2} \mathrm{O}$ respectively; after another ten minutes, ventilating with expiratory and inspiratory airway pressures of 10 and $30 \mathrm{~cm} \mathrm{H}_{2} \mathrm{O}$ respectively; and again after ten minutes of ventilation with expiratory and inspiratory pressures of 0 and $30 \mathrm{~cm} \mathrm{H}_{2} \mathrm{O}$ respectively. The final sample was taken at the end of operation, with the patient awake, lying supine, and breathing spontaneously 100 per cent oxygen by face mask. Blood samples in the case of patent ductus arteriosus were taken after division of the ductus.

During ventilation the inspiratory phase was approximately 40 per cent of the respiratory cycle. Airway pressures were measured with a manometer attached to the expiratory limb of the anaesthesia circle. Expiratory resistance was produced by manual compression of the anaesthesia bag.

$\mathrm{Pa}_{\mathrm{O}_{2}}, \mathrm{~Pa}_{\mathrm{CO}_{2}}$, and $\mathrm{pH}$ were determined by appropriate electrodes (Instrumentation Laboratory, Boston, Mass.) maintained at $37^{\circ} \mathrm{C}$. Microhaematocrit determinations were made on each blood sample. Buffer base values were obtained from the nomogram of Singer and Hastings. ${ }^{5}$ Oxygen saturations were determined with an oximeter (American Optical Co., Southbridge, Mass.). Whenever the $\mathrm{Pa}_{\mathrm{O}_{2}}$ values were higher than $150 \mathrm{~mm} \mathrm{Hg}$ and haemoglobin was fully saturated, the fractional shunt $Q_{\mathrm{S}} / \mathrm{Q}_{\mathrm{T}}$ was calculated by means of the modified shunt equation: ${ }^{6}$

$$
\frac{Q_{S}}{Q_{T}}=\frac{0.0031\left(\mathrm{PA}_{\mathrm{O}_{2}}-\mathrm{Pa}_{\mathrm{O}_{2}}\right)}{\mathrm{Ca}_{\mathrm{O}_{2}}-\mathrm{C}_{\mathrm{V}_{2}}+0.0031\left(\mathrm{P}_{\mathrm{A}_{2}}-\mathrm{Pa}_{\mathrm{O}_{2}}\right)} .
$$

For those studies with arterial oxygen tension lower than $150 \mathrm{~mm}$ and haemoglobin not fully saturated, the standard shunt equation was used:

$$
\frac{Q_{\mathrm{S}}}{Q_{\mathrm{T}}}=\frac{\mathrm{Cc}_{\mathrm{O}_{2}}-\mathrm{Ca}_{\mathrm{O}_{2}}}{\mathrm{Cc}_{\mathrm{O}_{2}}-\mathrm{C}_{\mathrm{O}_{2}}}
$$

in which the pulmonary capillary blood oxygen content

$$
\mathrm{Cc}_{\mathrm{O}_{2}}=0.0031 \times \mathrm{PA}_{\mathrm{O}_{2}}+\mathrm{Sc}_{\mathrm{O}_{2}}(1.34 \times \mathrm{Hb})
$$

and the arterial blood oxygen content

$$
\mathrm{Ca}_{\mathrm{O}_{2}}=0.0031 \times \mathrm{Pa}_{\mathrm{O}_{2}}+\mathrm{Sa}_{\mathrm{O}_{2}}(1.34 \times \mathrm{Hb}) .
$$

Alveolar oxygen tensions in both shunt equations were calculated as:

$$
\mathrm{PA}_{\mathrm{O}_{2}}=\mathrm{PB}-\mathrm{P}_{\mathrm{H}_{2} \mathrm{O}}-\mathrm{Pa}_{\mathrm{CO}_{2}}-\mathrm{P}_{\text {anesthetle agent }} \text {. }
$$

The arterial-mixed venous oxygen content difference $\left(\mathrm{Ca}_{\mathrm{O}_{2}}-\mathrm{C} \overline{\mathrm{v}}_{\mathrm{O}_{2}}\right)$ was assumed as 6 volumes $/ 100 \mathrm{ml}^{6}$ 


\section{RESULTS}

After premedication and before induction of anaesthesia the average $\mathrm{Pa}_{\mathrm{O}_{2}}$ was $71 \mathrm{~mm} \mathrm{Hg}$. The patient with the lowest $\mathrm{Pa}_{\mathrm{O}_{2}}(52 \mathrm{~mm} \mathrm{Hg})$ maintained lower than average levels of $\mathrm{Pa}_{\mathrm{O}_{2}}$ throughout the study (Table I). After induction of anaesthesia, with the pleural cavity open and both lungs ventilating with 100 per cent oxygen, all patients had arterial oxygen tensions higher than $200 \mathrm{~mm}$ $\mathrm{Hg}$ (mean 326) except the previously mentioned patient ( $159 \mathrm{~mm} \mathrm{Hg}$ ). After collapse of the non-dependent lung the mean arterial oxygen tension decreased to $170 \mathrm{~mm} \mathrm{Hg}$ (range 54-448). Five of the fourteen patients had oxygen tensions lower than $70 \mathrm{~mm} \mathrm{Hg}$.

Increasing the expiratory pressures decreased the mean oxygen tensions further to $120 \mathrm{~mm} \mathrm{Hg}$ (range $45-323$ ); two of the patients had arterial oxygen tensions as low as 45 and $47 \mathrm{~mm} \mathrm{Hg}$.

With return to normal expiratory pressure the mean $\mathrm{Pa}_{\mathrm{O}_{2}}$ levels increased to $196 \mathrm{~mm} \mathrm{Hg}$ (range 70-332).

At the end of operation, with the patient breathing spontaneously 100 per cent oxygen by face mask, the mean $\mathrm{Pa}_{\mathrm{O}_{2}}$ was $347 \mathrm{~mm} \mathrm{Hg}$ (range 181-480).

Mean pulmonary shunting was found to be 14 per cent of the cardiac output

TABLE I

$\mathrm{Pa}_{\mathrm{O}_{2}}$ and Pulmonary Shunting during Thoracotomy with Use of the Carlens Catheter

\begin{tabular}{|c|c|c|c|c|c|c|c|}
\hline \multirow{2}{*}{$\begin{array}{l}\text { Arterial } \\
\text { sample }\end{array}$} & \multirow[b]{2}{*}{ Patients } & \multirow[b]{2}{*}{ Condition } & \multirow[b]{2}{*}{$\mathrm{FI}_{\mathrm{O}_{2}}$} & \multicolumn{2}{|c|}{$\mathrm{PaO}_{2}(\mathrm{~mm} \mathrm{Hg})$} & \multicolumn{2}{|c|}{$\%$ shunt } \\
\hline & & & & mean & range & mean & range \\
\hline 1 & 10 & $\begin{array}{l}\text { before induction of } \\
\text { anaesthesia }\end{array}$ & 0.2 & 71 & $52-84$ & - & - \\
\hline 2 & 9 & chest open, both sides & & & & & \\
\hline 3 & 14 & $\begin{array}{l}\text { ventilating } \\
\text { ventilation with } 0\end{array}$ & 1.0 & 326 & $159-465$ & 14 & $9-21$ \\
\hline 4 & 14 & $\begin{array}{l}\text { expiratory airway } \\
\text { pressure* } \\
\text { ventilation with } 10 \mathrm{~cm}\end{array}$ & 1.0 & 170 & $54-448$ & 23 & $9-36$ \\
\hline 5 & 13 & $\begin{array}{l}\mathrm{H}_{2} \mathrm{O} \text { expiratory airway } \\
\text { pressure* } \\
\text { ventilation with } 0\end{array}$ & 1.0 & 120 & $45-323$ & 28 & $12-41$ \\
\hline & & $\begin{array}{l}\text { expiratory airway } \\
\text { pressure* }\end{array}$ & 1.0 & 196 & $70-332$ & 20 & $14-28$ \\
\hline 6 & 10 & $\begin{array}{l}\text { patients awake, } \\
\text { breathing spontaneously }\end{array}$ & 1.0 & 347 & $181-480$ & 13 & $7-19$ \\
\hline
\end{tabular}

*Non-dependent lung collapsed; there was a ten-minute interval between sampling times.

before and 23 per cent after collapse of the non-dependent lung (Table I). If cardiac output is assumed to be unchanged, the higher expiratory pressure increased the mean calculated shunting to 28 per cent. Return of expiratory pressure to previous levels $\left(0 \mathrm{~cm} \mathrm{H}_{2} \mathrm{O}\right)$ was followed by a decrease of shunting to 20 per cent. At the end of operation, pulmonary shunting was 13 per cent of cardiac output.

Before operation, nine of ten patients sampled had normal arterial carbon dioxide tension (Table II). One patient had a $\mathrm{Pa}_{\mathrm{CO}_{2}}$ of $53 \mathrm{~mm} \mathrm{Hg}$, indicating a respiratory depression probably due to premedication. The same patient also had the highest arterial carbon dioxide tension at the end of operation ( $59 \mathrm{~mm} \mathrm{Hg}$ ). 
TARHAN \& LUNDBORG: EFFECTS OF INCREASED EXPIRATORY PRESSURE

TABLE II

$\mathrm{Pa}_{\mathrm{CO}_{2}}, \mathrm{pH}$, and Buffer Base Values during Thoracotomy with Use of the Carlens Catheter

\begin{tabular}{|c|c|c|c|c|c|c|c|c|}
\hline \multirow{2}{*}{$\begin{array}{l}\text { Arterial } \\
\text { sample }\end{array}$} & \multirow[b]{2}{*}{ Patients } & \multirow[b]{2}{*}{ Condition } & \multicolumn{2}{|c|}{$\mathrm{Pa}_{\mathrm{CO}_{2}}(\mathrm{~mm} \mathrm{Hg})$} & \multicolumn{2}{|r|}{$\mathrm{pH}$} & \multicolumn{2}{|c|}{$\begin{array}{l}\text { Buffer base } \\
(\mathrm{mEq} / \mathrm{L})\end{array}$} \\
\hline & & & mean & range & mean & range & mean & range \\
\hline 1 & 10 & before induction of & & & & & & \\
\hline 2 & 9 & $\begin{array}{l}\text { anaesthesia } \\
\text { chest open, both sides }\end{array}$ & 39 & $31-53$ & 7.44 & $7.39-7.47$ & 50 & $42-56$ \\
\hline 3 & 14 & $\begin{array}{l}\text { ventilating } \\
\text { ventilation with } 0\end{array}$ & 26 & $22-29$ & 7.56 & $7.42-7.67$ & 49 & $45-55$ \\
\hline 4 & 14 & $\begin{array}{l}\text { expiratory airway } \\
\text { pressure* } \\
\text { ventilation with } 10 \mathrm{~cm}\end{array}$ & 29 & $22-37$ & 7.52 & $7.41-7.65$ & 48 & $44-57$ \\
\hline 5 & 13 & $\begin{array}{l}\mathrm{H}_{2} \mathrm{O} \text { expiratory } \\
\text { airway pressure* } \\
\text { ventilation with } 0\end{array}$ & 30 & $23-40$ & 7.49 & $7.4-7.6$ & 47 & $44-52$ \\
\hline 6 & 10 & $\begin{array}{l}\text { expiratory airway } \\
\text { pressure* }\end{array}$ & 28 & $21-37$ & 7.52 & $7.41-7.66$ & 47 & $44-52$ \\
\hline & & $\begin{array}{l}\text { oreatining } \\
\text { spontaneously }\end{array}$ & 46 & $37-59$ & 7.36 & $7.29-7.48$ & 49 & $42-54$ \\
\hline
\end{tabular}

*Non-dependent lung collapsed; there was a ten-minute interval between sampling times.

There was a tendency toward mild respiratory alkalosis during sampling periods 2 through 5. At the end of operation, with the patient awake and breathing spontaneously, the mean $\mathrm{Pa}_{\mathrm{CO}_{2}}$ values increased to $46 \mathrm{~mm} \mathrm{Hg}$ (range 37-59). Seven of ten patients had $\mathrm{Pa}_{\mathrm{CO}_{2}}$ values higher than $45 \mathrm{~mm} \mathrm{Hg}$, and six of these patients had a pH of less than 7.35, indicating respiratory depression and acidosis. Yet buffer base values remained in the normal range throughout the study.

\section{Discussion}

The adverse effects of age, ${ }^{7}$ premedication with narcotics, and pulmonary diseases $^{2}$ on arterial oxygen tension are known and explain the low preoperative values found in our patients.

Controlled ventilation with 100 per cent oxygen, with the patient in the lateral decubitus position and the pleural cavity open, provided oxygen tensions well above normal levels. Calculated pulmonary shunting of 14 per cent was not significantly different from that in non-thoracic surgical patients lying supine. ${ }^{8}$ An increase of $V / Q$ abnormalities has been reported in patients in the lateral decubitus position during thoracic surgery; ${ }^{9}$ it is apparent that ventilation with 100 per cent oxygen can compensate for these abnormalities.

Collapse of the non-dependent lung caused a decrease of mean $\mathrm{Pa}_{\mathrm{O}_{2}}$ values to $170 \mathrm{~mm} \mathrm{Hg}$, and four of the fourteen patients had values below $70 \mathrm{~mm} \mathrm{Hg}$. If this level of oxygen tension is accepted as the lowest safe level during anaesthesia in patients with normal or only slightly impaired cardiovascular function, ${ }^{1}$ the arterial oxygenation in those four patients was inadequate, yet alveolar ventilation by $\mathrm{Pa}_{\mathrm{CO}_{2}}$ criteria was normal or above normal in all patients.

The mean calculated pulmonary shunting was 23 per cent after collapse of the non-dependent lung. One might expect that with elimination of ventilation in a 
lung with normal blood flow, up to 50 per cent of the total cardiac output may shunt through the non-dependent lung. Since the shunt in these patients was less than 50 per cent, collapse of the lung also resulted in a decrease of pulmonary blood flow through the same lung.

It is known that during thoracic surgery, if the expiratory pressure is reduced to $0 \mathrm{~cm} \mathrm{H}_{2} \mathrm{O}$, a mediastinal shift toward the dependent lung occurs, ${ }^{3}$ causing atelectasis. This entity has also been confirmed by Craig and co-workers. ${ }^{10}$ Pulmonary shunting through those atelectatic areas also contributes to the decrease of $\mathrm{Pa}_{\mathrm{O}_{2}}$ levels. It would be expected that higher expiratory pressures would reinflate those atelectatic areas in the dependent lung and in tum increase the $\mathrm{Pa}_{\mathrm{O}_{2}}$ levels. In this study, with the institution of higher expiratory pressures, $\mathrm{Pa}_{\mathrm{O}_{2}}$ decreased in ten patients, was unchanged in one, and increased in three (Fig. 1).

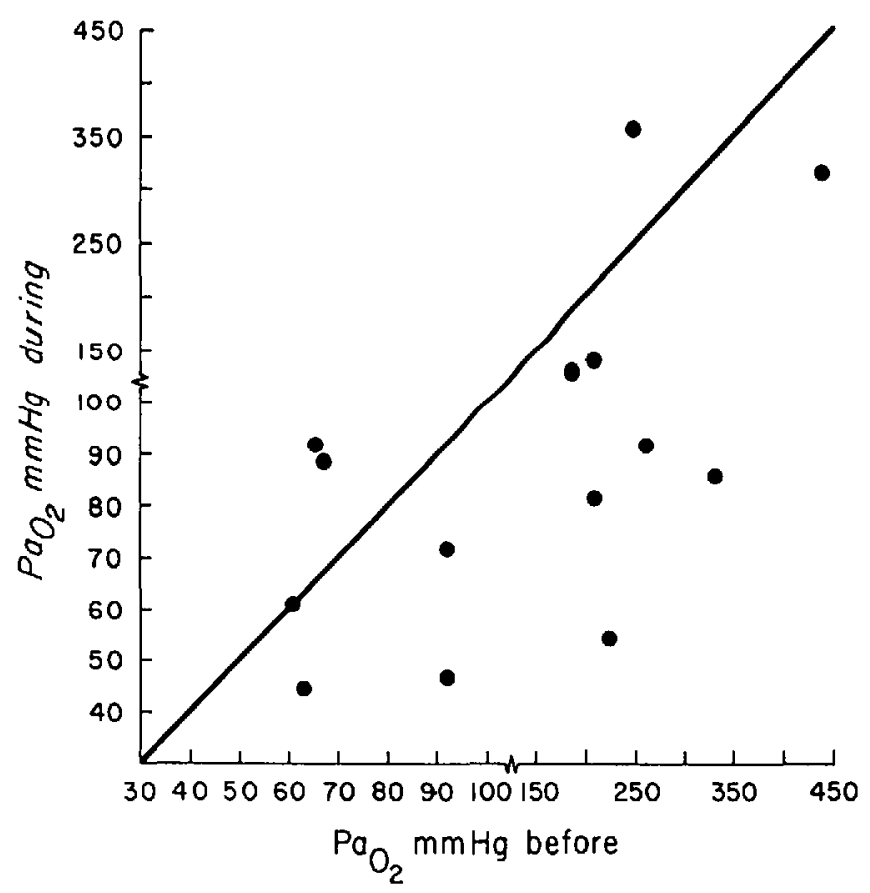

Figure 1. $\mathrm{Pa}_{2}$ before and during ventilation with increased expiratory pressure.

Such reduction of $\mathrm{Pa}_{\mathrm{O}_{2}}$ may be due to one or both of two mechanisms: a decrease in cardiac output and an increase in shunt. Increased airway pressure may decrease cardiac output, secondary to impairment of venous return and increase of pulmonary resistance or compression of the heart between the two lungs. ${ }^{11}$ With a constant oxygen consumption a decrease in cardiac output increases the quantity of oxygen extracted per volume of blood and decreases the mixed venous oxygen content. If the alveolar oxygen tension and the proportion of cardiac output shunting through non-ventilated alveoli are constant, then arterial oxygen tension would be reduced because of the admixture of a constant propor- 
tion of more desaturated mixed venous blood with the fully oxygenated pulmonary capillary blood. ${ }^{12}$

Circulatory compensation of increased airway pressure depends on maintenance of venous return, which in turn depends on peripheral venous tone. ${ }^{11}$ As to the effects of increased intrathoracic or expiratory pressures on cardiac output during thoracic surgery with the chest open, the only data available are those of Clowes and colleagues. ${ }^{13}$ They reported that the vena caval pressures increase after induction and remain between 15 and $18 \mathrm{~cm} \mathrm{H}_{2} \mathrm{O}$ on the average throughout thoracic surgery, which indicates that a circulatory compensation to maintain venous return does occur. During the period of increase in expiratory pressure, systolic blood pressure decreased $20 \mathrm{~mm} \mathrm{Hg}$ in two patients and approximately $10 \mathrm{~mm}$ in three. The reduced blood pressure returned to the previous level gradually before the 10 minutes of the sampling period ended. Some degree of circulatory compensation must have occurred. Compression of the heart between the two lungs also seems unlikely with one pleural space open.

The more likely mechanism has been suggested by Hill and colleagues. ${ }^{14}$ In dogs with the chest open, the right lung was ventilated with 100 per cent oxygen and the left lung was rendered atelectatic with the Carlens catheter; an increase in peak inflation pressure caused an increase of shunting through the atelectatic lung. When the peak inflation pressure was between 16 and $23 \mathrm{~cm} \mathrm{H}_{2} \mathrm{O}$, the atelectatic lung received an average of 31 per cent of the total pulmonary blood flow.

In the present study, application of increased expiratory pressure may have tended to reopen some atelectatic areas in the dependent lung, yet the increase of pulmonary vascular resistance may have diverted a bigger portion of pulmonary flow through the atelectatic lung, causing a larger pulmonary shunt and a decrease of $\mathrm{Pa}_{\mathrm{O}_{2}}$.

When the expiratory resistance was released, there was an increase in $\mathrm{Pa}_{\mathrm{O}_{2}}$ which was higher than the values obtained prior to ventilation using increased expiratory pressure (Fig. 2). Also, there was a corresponding decrease of pulmonary shunting indicating that some atelectatic areas reopened in the dependent lung. Similar observations were also made by Cheney and colleagues ${ }^{12}$ in non-thoracic surgical cases.

Before closure of the chest, sustained inflations applied to the airway and re-expansion of the non-dependent lung were accomplished under direct vision in the patients who had not had pneumonectomy. Low arterial oxygen and high carbon dioxide tensions are common findings after thoracotomy and may be due to venous admixture or alveolar hypoventilation or both. ${ }^{2}$ However, the calculated pulmonary shunt at 13 per cent of cardiac output was not significantly different from that in the postoperative non-thoracic surgical patients. ${ }^{15}$ But seven of ten patients had a $\mathrm{Pa}_{\mathrm{CO}_{2}}$ above normal range, indicating alveolar hypoventilation.

\section{SUmMary and Conclusions}

Blood gases and acid-base status of fourteen patients undergoing thoracic surgery were studied. All patients were intubated with the Carlens catheter. A 


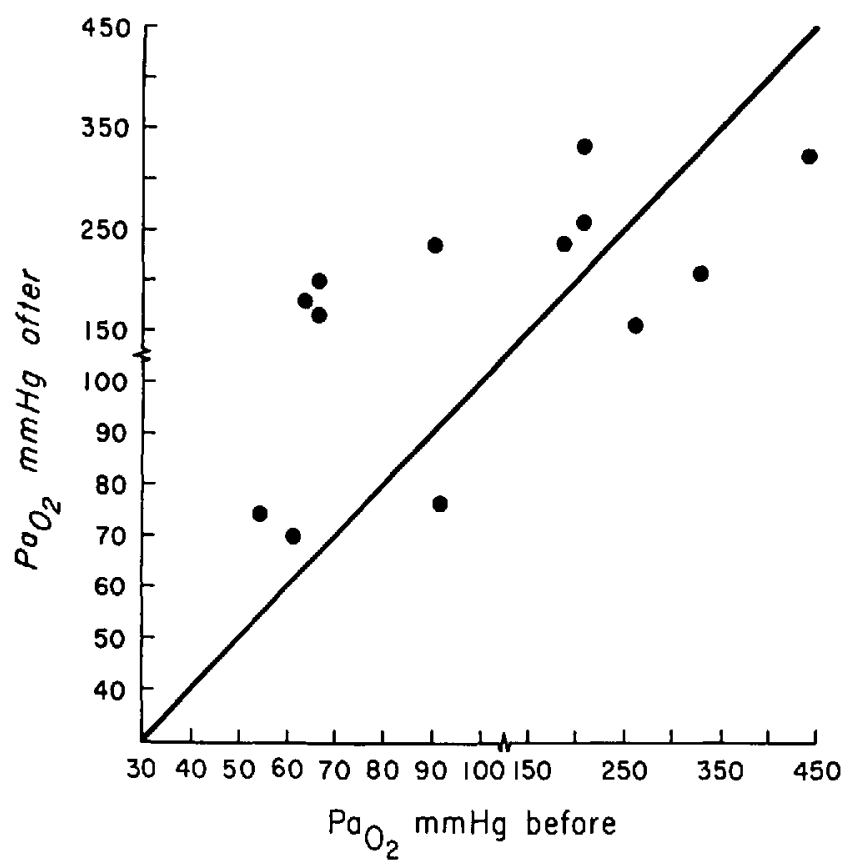

FIGURE 2. $\mathrm{Pa}_{\mathrm{O}_{2}}$ before and after ventilation with increased expiratory pressure.

large degree of pulmonary shunting and corresponding hypoxaemia was often seen during collapse of one lung. Attempts to prevent the mediastinal shift and to reverse atelectasis in the dependent lung with increased expiratory pressure further decreased arterial oxygen tension in most patients. The mechanism involved in this adverse effect is most likely an increase of shunting through the collapsed non-dependent lung. However, effects of decreased cardiac output on these parameters cannot be excluded from the present study.

Increased expiratory pressure appears to reverse collapse of air spaces, but its effect on $\mathrm{Pa}_{2}$ was not seen until after release of the pressure. This type of ventilation does not seem to be effective in correcting the hypoxaemia that may accompany the use of the Carlens catheter during thoracic surgery.

\section{RÉSUMÉ}

On a étudié les gaz sanguins et l'équilibre acide-base de 14 malades soumis à la chirurgie thoracique. Tous les malades ont été intubés par le tube Carlens. On a souvent observé durant le collapsus d'un poumon un degré important de "shunt" pulmonaire et d'hypoxémie correspondante. Des tentatives pour prévenir le déplacement médiastinal et pour renverser l'atélectasie dans le poumon contrôlé à l'aide d'une pression expiratoire augmentée a diminué davantage le tension d'oxygène artériel chez la plupart des malades. Le mécanisme impliqué dans cet effet contraire est probablement une augmentation du "shunt" à travers le poumon collabé. Cependant, d'après cette étude, les effets d'un débit cardiaque diminué sur ces paramètres ne peuvent pas être exclus.

Une pression expiratoire augmentée semble renverser le collapsus des alvéoles, 
mais son effet sur la $\mathrm{Pa}_{\mathrm{O}_{2}}$ n'a été observé qu'après cessation de la pression. Ce genre de ventilation ne semble pas efficace pour corriger l'hypoxémié qui peut accompagner l'emploi du tube Carlens durant la chirurgie thoracique.

\section{REFERENCES}

1. Lunding, M. \& Fennandes, A. Arterial Oxygen Tension and Acid-Base Status during Thoracic Anesthesia: With Special Reference to the Effort of Total Collapse of One Lung as Obtained by Using Double-Lumen Tubes. Acta anaesth. Scandinav. 11: 43 (1967).

2. Tarhan, S. \& Lundiong, R. O. Blood Gas and pH Studies during Use of the Carlens Catheter. Canad. Anaesth. Soc. J. 15: 458 (1968).

3. Tappin, A. R. The Control of Positive Intrapulmonary Pressure during Thoracotomy. Anaesthesia. 24: 108 (1969).

4. Frume, M. J.; Bergman, N. A.; Holaday, D. A.; Rackow, H.; \& Salanitre, E. Alveolar-arterial $\mathrm{O}_{2}$ Differences during Artificial Respiration in Man. J. Appl. Physiol. 14: 694 (1959).

5. Singer, R. B. \& Hastincs, A. B. An Improved Clinical Method for the Estimation of Disturbances of Acid-Base Balance of Human Blood. Medicine. 27: 223 (1948).

6. Laver, M. B. \& SEifen, A. Measurement of Blood Oxygen Tension in Anesthesia. Anesthesiology, 26: 73 (1965).

7. Raine, June M. \& Bishop, J. M. A-a Difference in $\mathrm{O}_{2}$ Tension and Physiological Dead Space in Normal Man. J. Appl. Physiol. 18: 284 (1963).

8. Mrchenfelder, J. D.; Fowlen, W. S.; \& Theye, R. A. $\mathrm{CO}_{2}$ Levels and Pulmonary Shunting in Anesthetized Man. J. Appl. Physiol. 21 : 1471 (1966).

9. Virtue, R. W.; Permutt, S.; Tanaka, R.; Pearcy, C.; Bane, H. N.; \& BnombergerBarnea, B. Ventilation-Perfusion Changes During Thoracotomy, Anesthesiology. 27: $132(1966)$.

10. Craig, J. O. C.; Bromley, L. L.; \& Williams, R. Thoracotomy and Contralateral Lung: A Study of the Changes Occurring in the Dependent and Contralateral Lung during and after Thoracotomy in Lateral Decubitus. Thorax. 17: 9 (1962).

11. Andensen, M. N. \& Kucriba, K. Depression of Cardiac Output With Mechanical Ventilation: Comparative Studies of Intermittent Positive, Positive-Negative, and Assisted Ventilation. J. Thorac. Cardiov. Surg. 54: 182 (1967).

12. Cheney, F. W.; Honnbein, T. F.; \& Chawfond, E. W. The Effect of Expiratory Resistance on the Blood Gas Tensions of Anesthetized Patients. Anesthesiology. 28: 670 (1967).

13. Clowes, G. H. A., Jr.; Alichniewicz, A.; Del Guercio, L. R. M.; \& Gillespie, D. The Relationship of Postoperative Acidosis to Pulmonary and Cardiovascular Function. J. Thorac. Cardiov. Surg. 39: 1 (1960).

14. Hill, T. R.; Finley, T. N.; Takamura, J. H.; Orallo, M.; \& Bonica, J. J. The Effect of Inflation Pressure in the Contralateral Lung on Blood Flow through an Atelectatic Lung in the Dog. (Abstr.) Fed. Proc. 21: 108 (1962).

15. Tarhan, S.; Moffitr, E. A.; \& Sessler, A. D. The Effect of Dead-Space Rebreathing on Postoperative Atelectasis. Anesth. \& Analg. 48: 721 (1969). 